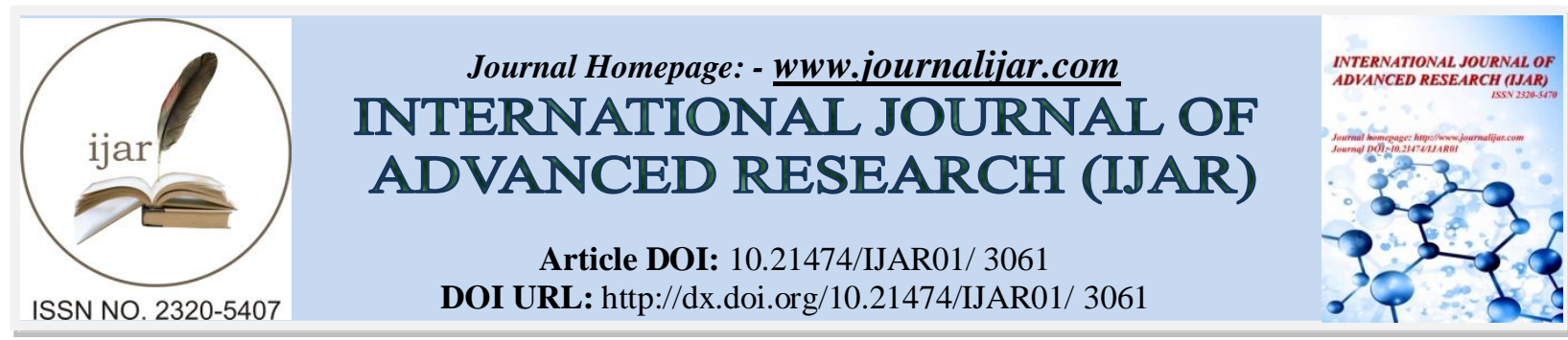

RESEARCH ARTICLE

\title{
STUDY ON CORPORATE SOCIAL RESPONSIBILITY INITIATIVES OF INDIAN COMPANIES.
}

\author{
Vikrant Vikram Singh ${ }^{1}$, Dr. Manoj Pandey ${ }^{2}$ and Prof. (Dr.) Anil Vashisht ${ }^{3}$. \\ 1. Assistant Professor, Amity Business School, Amity University Madhya Pradesh. \\ 2. HOD, Amity Business School, Amity University Madhya Pradesh. \\ 3. Director, Amity Business School, Amity University Madhya Pradesh.
}

\section{Manuscript Info}

..........................

Manuscript History

Received: 01 December 2016

Final Accepted: 29 December 2016

Published: January 2017

\section{Abstract}

The purpose of this study is to explore the various definitions anddescriptions of Corporate Social Responsibility (CSR); elaborate upon development ofCSR in India; study the theoretical concepts expounded by various researchers andstudy the deployment of current CSR practices in India. This paper examines howIndia's top companies view, and conduct their CSR, identifies key CSR practicesand maps these against Global Reporting Initiative standards. The study is divided into various sections: After giving a genesis and background of the subject,the next section gives a review of literature covering various facets and areas, which are touchedupon by corporate social responsibility, including the arguments put forward both for and againstCSR. Further sections deals with the methodology adopted for the study. The fourth section talksabout the Indian experience in the area. The fifth section presents the main findings of the study,collected through the questionnaires sent to all the companies and collated by the research team. The last section enumerates the concluding observation and lessons forfuture.

Copy Right, IJAR, 2016,. All rights reserved.

\section{Introduction:-}

The role of business in society has been debated in economic literature for a long time. By the term 'Corporate Social Responsibility' (CSR), what is generally understood is that business has anobligation to society that extends beyond its narrow obligation to its owners or shareholders. Thisidea has been discussed throughout the twentieth century, but it was Howard R. Bowen's book on "Social Responsibilities of Businessman" published in 1953, which was the origin of the moderndebate on the subject. Bowen reasoned that there would be general social and economic benefits thatwould accrue to society, if business recognized broader social goals in its decisions.

Corporate Social Responsibility is nothing but what an organization does to positivelyinfluence the society in which it exists. It could take the form of community relationship, volunteerassistance programmes, healthcare initiatives, special education / training programmes andscholarships, preservation of cultural heritage and beautification of cities. The philosophy is, basicallyto give back to the society, what it (business) has taken from it, in the course of its quest for creationof wealth.

On the one hand experts have argued that shareholders put their risk capital in a Joint StockCompany (or business) and therefore, companies should be managed in the interest of the owners orthe shareholders. This primacy of

Address:- Assistant Professor, Amity Business School, Amity University Madhya Pradesh. 
treatment given to the shareholders is being justified on thegrounds of ownership and shareholding. It is felt that maximisation of profits or the bottom lineshould be the ultimate objective of the management. On the other hand, a number of experts willnot agree with this position. For example, in Japan employees are treated as family. It is felt that anemployee who devotes his or her life to the company has a bigger stake in it as compared to ashareholder. Germany is another nation where stakeholder recognition is high. Prominent among theexperts who has taken a broader view is Minks who has argued that any company with a short termin view, only maximizing profits for the shareholders, will destroy value in the medium to long run.

It is felt that the moot point here is the time frame. And that in the long run, thesustainability of the enterprise will be of paramount importance. In the long run, interests of both thestakeholders and the shareholders are not only likely to converge, but also have to be balanced.

The more the concepts of CSR are fostered and integrated into the business process, the easier itwill be to benefit from alternative thinking and perhaps handle the occasional problems that forcertain will occur. The more integrated the business process within the value chain, the moreopportunity there will be for organizations to influence the approaches of others on whom theydepend. The concept of CSR includes the openness or transparency of companies as well astaking into consideration the will and expectations of their stakeholders.

Social responsibility means a doctrine that claims that an entity whether it is government, Private Corporation or public organization has a responsibility to society. CSR is a concept that reducescosts and risks, increases the brand value and reputation, effectiveness and the efficiency ofemployees, improves transparency, and clarity in the working environment of the businesshouse.

The main drivers for CSR have been the shrinking role of government, demands for greaterdisclosure, increased customer interest, growing investor pressure, competitive labor markets, and supplier relations. The companies enjoy several benefits like improved financialperformance, lower operating costs, enhanced brand image and reputation, increased sales andcustomer loyalty, product safety, material recyclability, and greater use of renewable resourcesetc.

\section{CSR in India:-}

\section{CSR History:-}

India has a long rich history of close business involvement in social causes for nationaldevelopment. In India, CSR is known from ancient time as social duty or charity, which throughdifferent ages is changing its nature in broader aspect, now generally known as CSR. From theorigin of business, which leads towards excess wealth, social and environmental issues havedeep roots in the history of business. India has had a long tradition of corporate philanthropy andindustrial welfare has been put to practice since late 1800s. Historically, the philanthropy ofbusiness people in India has resembled western philanthropy in being rooted in religious belief.

Business practices in the 1900s that could be termed socially responsible took different forms:philanthropic donations to charity, service to the community, enhancing employee welfare andpromoting religious conduct. Corporations may give funds to charitable or educationalinstitutions and may argue for them as great humanitarian deeds, when in fact they are simplytrying to buy community good will. The ideology of CSR in the 1950s was primarily based on anassumption of the obligation of business to society.

In initial years there was little documentation of social responsibility initiatives in India. Sincethen there is a growing realization towards contribution to social activities globally with a desireto improve the immediate environment (Shinde, 2005). It has also been found that to a growingdegree companies that pay genuine attention to the principles of socially responsible behavior arealso favored by the public and preferred for their goods and services. This has given rise to theconcept of CSR.

After Independence, JRD Tata who always laid a great deal of emphasis to go beyondconducting themselves as honest citizens pointed out that there were many ways in whichindustrial and business enterprises can contribute to public welfare beyond the scope of theirnormal activities. He advised that apart from the obvious one of donating funds to good causeswhich has been their normal practice for years; they could have used their own financial,managerial and human resourced to provide task forces for undertaking direct relief andreconstruction measures. Slowly, it began to be accepted, at least in theory that business had toshare a part of the social overhead 
costs of. Traditionally, it had discharged its responsibility tosociety through benefactions for education, medical facilities, and scientific research amongother objects. The important change at that time was that industry accepted social responsibility

\section{Review of Literature:-}

TulsiJayakumar (2013) considered whether CSR correspondence issues are diverse in rising economies rather than Western created economies, requiring an alternate worldview of CSR Communication. An inside and out investigation of an Indian MNC auxiliary Hindustan Unilever Ltd. also, an Indian multinational, ICICI, uncovers that both organizations have been rehearsing CSR for quite a while and utilizing an Endorsed system of correspondence instead of the Expert Communication favored by Western standards. This is by virtue of the complex socio social milieu of such EDE resembles India which posture particular imperatives on the Communication procedure. All things considered, they either don't take after/are late participants into the field of corporate reporting utilizing GRI/UNGC standards.

M Indira\&Siddaraju V G (2009)analyzed the CSR of TVS Motor organization by taking after a contextual analysis strategy. TVS Motor organization is situated at Nanjanagud, Mysore locale of Karnataka. The organization's revelations propose that it is taking up a few activities to enhance the states of the underprivileged in the general public and have a constructive outcome in their lives. Notwithstanding the group activities, TVS Company has been working with the NGOs, nearby powers and organizations, and neighborhood pioneers and government offices. They examined the CSR goals of TVS Company, their ability to recognize social issues, usage of methodologies and changes in the techniques after globalization, social pertinence of the issues tended to by the organization, and the state of mind of the chiefs in the organization towards CSR.

V Ashotosh et al (2014) studied the expenditure pattern of corporates towards CSR activities in the period of voluntary spending and based on the results, evaluated whether insertion of such a provision in the Act was necessary or not. They took sample consists of thirty companies included in BSE Sensex from 2001 to 2012. The analysis was done on the basis of number of companies spending on CSR, details of CSR expenditure, amount of CSR spending as percentage of sales and profits for each year and on an overall basis. The analysis showed that the CSR spending has been very low as percentage of revenue and profits during the phase of voluntary spending. The results also suggested that spending on environment and pollution control is not on the priority list of companies. Though, impact of CSR activities cannot always be evaluated in terms of fund allocations, still it is one of the most important indicators of the engagement of companies with society. Therefore, based on the findings, they concluded that insertion of this provision was an appropriate step by the regulators to make corporates socially more responsible.

B Prema (2009) analyzed the impact analysis of microfinance programme which was undertaken a decade ago by Forbes Marshall India Ltd, Pune. The analysis was based on primary data collection of 217 SHG members of SHGs formed by the company through the interview technique.

Study suggested that the microfinance has resulted in increasing the economic empowerment of SHG members belonging to weaker socio economic class. The paper also concluded that the level of economic empowerment of SHG members increases with the number of years of association with the SHG. At the end some suggestions were incorporated to give new directions to microfinance programme to fulfill new aspirations of SHG members.

J Tulsi (2013)analysed the CSR practices followed by HUL in its unit in DoomDooma, Assam in the period 2001 2004, a period which was one of the most tumultuous periods in the history of HUL operation in India. The largest personal care products factory set up in DoomDooma to take advantage of the government's concessions to encourage the region's development, witnessed serious challenges in the form of local bandhs (closures) and followed by an attack by the militant group, ULFA. Yet, the productivity contribution of the Assam factory was one of the highest and in fact was responsible for the company's top line growth.

She suggested that the financial performance was due in no small measure, to the corporate responsibility measures undertaken internally and externally by the company. The former consisted of the measures undertaken vis à vis the key stakeholders, viz. employees, consumers, ecosystem, and business partners while the external CR measures were with respect to the specific CSR initiatives undertaken keeping in mind the needs and expectations of the local community. Thus, the company's CR initiatives helped in sustainable growth. 
She investigated whether firms operating in conflict zones can survive and sustain profitable business operations in the midst of a conflict using the tool of CSR. The objective was to see if an MNC can, through the employment of CSR, gain acceptability of a community which is confronted with social challenges and conflict, and in turn, can use such legitimacy for enhancing the value of its stakeholders. It does so by carrying out an in depth study of one of the oldest MNCs and the largest Fast Moving Consumer Goods (FMCG) company operating in India - Hindustan Unilever Limited (HUL), following the case study method of analysis. The case pertained to the CSR initiatives undertaken by HUL in its unit in Doom Dooma, Assam in the period 20012004.

C Barnali\& G Neeran (2013) examined the CSR initiative of Coca Cola India1 through public private partnership method for contribution towards Water Management in Kaladera region by involving the government and the local community. They concluded that Setting up the plant in Kaladera resulted in strong resistance and protests of local residents. The company transformed the resistance into enormous popularity through its CSR activities and by involving the stakeholders in the execution and implementation of its plan. Coca Cola - India now enjoys local favor as it succeeded in translating the issues of the local community of Kaladera. The action plans had done wonders for boosting up the confidence level of the villagers and changing the perception about the company. Initially skeptical, the villager's apathy gradually gave way to mutual trust and cooperation.

W Philippa et al (2013) tried to explore the matter of whether such directors are influencing corporates in their sustainability and CSR policies. Within a framework shaped by Institutional theory, and via an examination of the publicly available published reports and other documented information on the Top 50 companies on the New Zealand Exchange (the NZX), they explored this question. The initial findings from this examination suggested that the reporting and performance record for these New Zealand corporates was both disappointing and limited. The finding was all the more interesting in light of the country's global " $100 \%$ pure" marketing mantra and the environmentally responsible image and reputation the country seeks to cultivate internationally.

SumonaGhosh( 2015) investigated the pattern of communication of CSR information among the private sector companies in India, she pointed out that as reflected in the corporate websites taking absolute profit as the parameter and show that the corporate sector in India is yet to fully recognize the value of open communication about CSR practices to meet the needs of an increasingly transparent marketplace and to help build corporate reputation.

They concluded that companies belonging to higher deciles reported more substantial information about their CSR activities, than those belonging to the lower deciles, but the companies preferred to report more on pursuit of CSR activities with/through the help of foundations/ trusts/NGOs/government partnerships than crucial issues like disclosure of financial information on CSR activities. Thus, richness of the content with respect to disclosure of the number of beneficiaries that were benefitting from their CSR activities and the disclosure of financial information on CSR activities in the official websites was very shallow.

N.K.Nair\& J.S. Sodhi (2012) analyzed the major findings of five case studies on the best CSR practices by Indian SMEs prepared by a team of researchers from Shri Ram Centre for Industrial Relations \&Human Resources, New Delhi. They recommended that a lead institution may be nominated in each district to serve as a mediator. They also pointed out that supply chain pressures/opportunities to induce increasing number of SMEs to resort to CSR initiatives have been found missing. Finally they suggested that all the case examples presented in their study bear testimony to the need for the local comniunity's involvement /support, directly or indirectly, to the full/partial success of SMEs' CSR initiatives. The least that could be done by the Ministry of Micro, Small \& Medium Enterprises (MSME) is to recognize the CSR initiatives by SMEs through a suitably designed scheme of national awards.

\section{Objectives of the Study:-}

1. To study the CSR Initiatives of leading companies in India.

2. To analyze and comparison of CSR practices and Ethics of various companies in India.

3. To study and explore the various areas of CSR activities done by Indian Companies.

\section{Research Methodology:-}

The present study is based on data / information collected from large sized Indian companies, morespecifically from those companies that were included in the National Stock Exchange's broad basedindex - S\&P CNX NIFTY, during 
January 2014-15. This represents fifty companies, with issued capitalof Rs. 96,108 million and market capitalisation of Rs. 3,024,720 million.

A structured questionnaire was sent to all the companies through post, explainingthe background and objectives for undertaking the study.

Despite close, rigorous follow-up, spread across two months, through e-mail, letters,telephone calls and even personal visits, response was received from only 19 companies. Two of thecompanies responded by saying the information was confidential and regretted their inability to shareit with us. This was despite our assurance in writing that data would be consolidated and companies'names would not be revealed. Data for an additional 11 companies was culled out from otherpublished sources as detailed in section on the main findings of the study later.

The purpose of thedocumentation is to bring out the similarities and differences of social responsibility initiatives, theirdecision making process, implementation modes and review mechanisms.

The review of literature as also the section on Indian experience is an attempt to put theentiregamut of discussions, developments on the CSR front in a perspective against which our owndata is analysed and interpreted.

\section{Indian Experience:-}

There has been very little systematic documentation of Social Responsibility initiatives of corporatesin India in the past, other than the brochures and publicity material brought out by the companiesthemselves. But in the last 3-4 years, 2 important surveys have been conducted, which have somesignificant macro level conclusions about India Incorporated and their journey on the socialresponsibility front.

Serious and committed approach to corporate responsibility practices is increasing its reach,but there is a vast ground yet to be covered. Corporate sector is slowly realising the positive aspectsof corporate responsibility practices (good for business is good business). There is growingcollaborative work between NGOs and companies. All stakeholders are increasingly becomingaware of the diverse facets of corporate responsibility practices. Due various internal and externalpressures, the climate is conducive for the growth of corporate responsibility practices in India.

Although many companies, NGOs and trade unions were aware of corporate responsibilitypractices, the study findings suggest that the concepts has yet to become part of core businessstrategy in most companies in India. Almost all companies, irrespective of size and sector had someawareness of corporate responsibility and its potential benefits. While most companies also hadpolicies in place related to labour issues, community relations and environmental practices, they werefor the most part not backed up by comprehensive implementation and monitoring systems.

Community programmes or social development initiatives, in most cases, were philanthropic and/orad hoc in nature and not integrated into core business activities such as marketing and brandmanagement.

Analysis \& Findings of the Study:-

A structured questionnaire, specially designed for the study, was sent to all the fifty companiesincluded in the NSE NIFTY Index.

It is appropriate to mention here that despite rigorous, consistent and close follow up withthe companies through courier, telephone, e-mail and at times through personal visits, the responseto the questionnaire has not been encouraging at all. Out of the 50 companies, only 19 companieshave responded to the questionnaire. To make the sample more representative, we have been able toextract some / most of the information pertaining to the subject for an additional 11 companiesfrom a) the published annual reports, b) director's reports, c) brochures published by the companiesfrom time to time and d) other articles etc published about the CSR initiatives of these companies inreputed journal and financial dailies and weeklies. Thus, the total number of companies for which thedata is available is 30, which is $60 \%$ of the companies selected for the analysis. Considering theresponse to some of the earlier attempts made to document / study the area, by Chambers ofCommerce, along with some multilateral agencies, the response may be considered reasonable. 
The following table gives the sector wise composition of the NIFTY companies and similaranalysis for the responding companies:

\begin{tabular}{|l|l|l|}
\hline Sector & Composition of & \multicolumn{2}{|c|}{ *Responding Cos } \\
\hline & All NIFTY Cos & $89.5 \%$ \\
\hline Private Sector Indian Cos & $72 \%$ & $3.5 \%$ \\
\hline Multi National Cos & $12 \%$ & $7 \%$ \\
\hline Public Sector Cos & $16 \%$ & $100 \%$ \\
\hline Total & $100 \%$ & \\
\hline
\end{tabular}

*Refers to only those companies that responded to the questionnaire.

The following are some general observations on the responding companies, which may beuseful to keep in view while analysing the response:

a. None of the computer software / hardware companies have responded to thequestionnaire,with just one exception.

b. Only two public sector undertaking have responded to our questionnaire. This is despitethe well-known fact that many of them are active in the social responsibility areas.

c. Out of the seven Tata Group companies included in the NIFTY list, as many as fivehave responded.

d. Responses have come from different departments and offices within the companies, likethe Office of the Company Secretary, Human Resource Department, and Departmentof Corporate Communications and in couple of cases from Ethics Counselors andspecially created Department for Social Initiatives.

The important findings of the study are discussed in the following paragraphs:-

I) About $57 \%$ of companies in the sample have a formally adopted ethics code. Thenomenclature for these codes varies from company to company: Some companies call it'Code of Conduct', others 'Core Statement of Values' and still others by some other name.

All these companies are treated, for the purpose of our analysis as having an Ethics Code.

One third of the companies do not have a formally adopted code, while for $10 \%$ of thecompanies the information is not available.

About the process through which the code has been evolved, most companies have chosento remain silent. Few companies have offered the following information and comments:

$>$ Historically evolved

$>$ Before adoption discussed among senior management and board of directors

$>$ Before adoption discussed with present as well as past employees

$>$ Studied \& attempted to incorporate international standards and best practices

$>$ Democratically evolved

Just one third of the companies have an Ethics Officer or an Ethics Counselor. Another $40 \%$ of thecompanies do not a specifically designated officer, but many of these companies have indicated thatother departments and or offices look after this function. $27 \%$ of the companies have not given anyinformation.

\begin{tabular}{|l|l|l|l|l|l|l|}
\hline & \multicolumn{2}{|c|}{ Cos having one } & Cos Not having one & \multicolumn{2}{l|}{ Information NA } \\
\hline & Number & $\%$ & Number & $\%$ & Number & $\%$ \\
\hline & & & & & & \\
\hline Formal Ethics Code & 17 & 57 & 10 & 33 & 03 & 10 \\
\hline $\begin{array}{l}\text { Ethics Officer / Ethics } \\
\text { Counselor }\end{array}$ & 10 & 33 & 12 & 40 & 08 & 27 \\
\hline
\end{tabular}

II) As far as the areas of interventions or content of the social responsibility initiatives isconcerned, these have been classified into seven major areas as listed in Table below. Mostcompanies are active in more than one area and therefore, the total does not add up to 100per cent, but is more than that. 


\begin{tabular}{|l|l|l|l|}
\hline Sr. & Area of CSR Interventions & Number of Cos & No Percentage of Cos @ \\
\hline 1 & Education / Training & 24 & 80 \\
\hline 2 & Health Care & 20 & 66 \\
\hline 3 & Environment & 18 & 60 \\
\hline 4 & Religious / Spiritual & Nil & Nil \\
\hline 5 & Welfare of Under privileged Sections & 17 & 57 \\
\hline 6 & Rural Development & 7 & 23 \\
\hline 7 & Natural \& Other Calamities & 14 & 46 \\
\hline 8 & Any Other & 12 & 40 \\
\hline
\end{tabular}

Areas in which large proportions of the sample companies are active are Education \&training ( $80 \%$ ), Healthcare ( $66 \%$ ), Environment ( $60 \%$ ), Welfare of under privilegedsections of the society ( $57 \%$ ) and Rural development ( $23 \%)$.

There are two surprising results, which emerge out of the above analysis -

Firstly, none of the companies have said that they are doing anything actively in thearea of religion and spiritual development. While it is well known that a number ofcompanies, some of them belonging to some particular industrial groups, are doinga lot in this area. One probable reason for this could be that these activities arebeing undertaken by trusts formed specifically for the purpose, though under theumbrella of the group.

Second, surprising finding is that less than half (more specifically only $46 \%$ ) of thecompanies in the sample have mentioned natural \& other calamities as part of thearea in which they are active. One would have probably expected all companies tobe doing their bit in this area.

\section{References:-}

1. JTulsi (2013), "CSR Communication in Emerging Economies: Need for a New Paradigm: A Case Study of a Multinational and an Indian Trans National's CSR Communication in India", IJBIT, volume 6 issue 4 April, pp 6677.

2. M Indira\&Siddaraju V G (2009), "Do Corporates Have Social Responsibility?A Case Study of TVS Motor Company", The Icfai University Journal of Corporate Governance, Vol. VIII, Nos. 3 \& 4, pp 131138.

3. V Ashotosh\&C. V. R. S. Vijaya Kumar (2014), "An Analysis of CSR Expenditure by Indian Companies", Indian Journal of Corporate Governance, Volume 7, No. 2, JulyDecember 2014, pp 8294.

4. B Prema (2009), "Economic Empowerment Through Microfinance,An Assessment of CSR Activity run by Forbes Marshall Ltd.”, International journal of business insights \& transformation, October 08 March 09, pp 64 74.

5. J Tulsi (2013), “MNC CSR in Emerging EconomyConflict Zones A Case Study ofHUL's NorthEast Operations in India", VIKALPA, VOLUME 38, NO 4 ,OCTOBER DECEMBER 2013, pp 6982

6. C Barnali\& G Neeran (2013), "Efficient Water Management throughPublicPrivate Partnership Model:An Experiment in CSR byCocaCola India, VIKALPA, VOLUME 38, NO 4, pp 9714

7. W Philippa et al (2013), "Corporate Sustainability/CSR and the Influence of the Independent Director: " $100 \%$ Pure"NewZealand, European Conference on Management, Leadership \& Governance, pp 372380.

8. SumonaGhosh (2015), "Proactive Communication of CSR in India: A Distant Dream or Reality?",Paradigm , 19(2) 115-136, SAGE Publications, DOI: 10.1177/0971890715609845, http://par.sagepub.com.

9. N.K.Nair\& J.S. Sodhi (2012), "CSR Practices by SMEs in India: Lessons from Five Case Studies" The Indian Journal of Industrial Relations, Vol. 47, No. 4, April 2012. 